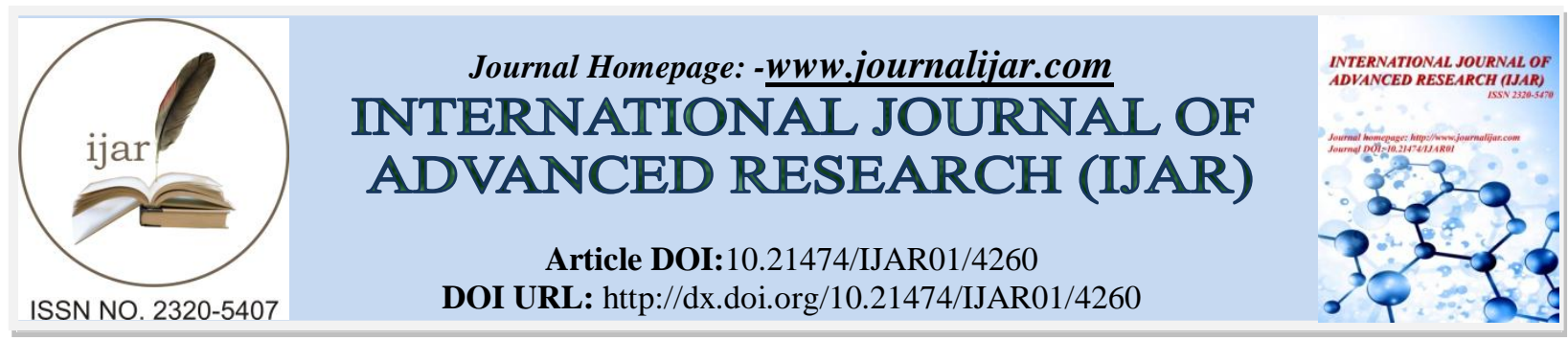

RESEARCH ARTICLE

\title{
A MODEL FOR REINFORCING THE IMPLEMENTATION OF SCIENTIFIC APPRAOCH IN LANGUAGE LEARNING.
}

Aris Badara and Hilaluddin Hanafi.

Lecturer, Indonesian Language and Arts Education, Faculty of Teacher Training and Education, Halu Oleo University.

\section{Manuscript Info}

Manuscript History

Received: 27 March 2017

Final Accepted: 30 April 2017

Published: May 2017

Key words:-

scientific approach, learning model, observing method, questioning method, associating method, experimenting method

\section{Abstract}

Teachers' skills in applying scientific approach are generallystill poor. For this reason, the application of scientific approach needs to be reinforced in order to ensure that the characteristics of the approach appear in learning. Findings of this study show that the reinforcements must be provided on five main learning experiences, namely (a) observing, (b) questioning, (c) experimenting, (d) associating, and (e) communicating. In particular, the reinforcements need to be focused onthese aspects: (a) meaningfullearning process, (b) teacher's ability in increasing learners' reasoning skills, (c) teacher's ability to improvise with different teaching methods, (d) a learning that is oriented towards measurable results, (f) teacher's ability in giving drills and exercises systematically, and (h) teacher's ability in documenting learner's progress. In addition, teachers are required to make themselves very familiar with some learning models that are compatible with the scientific approach, including (a) inquirylearning, (b) discoverylearning, (c) project-based learning, and (d) problembased learning.

Copy Right, IJAR, 2017,. All rights reserved.

\section{Introduction:-}

Scientific approach is one of the essentialcomponents of 2013 curriculum. However, teachers at all tiers of education are still experiencing difficulties in applying the approach. To make matter worse, our governmentsboth at local and national levelhave been unable yet to disseminate the scientific approach in a systematic way. A particularly serious problem is teacher's poor ability in applying the scientific approach in classrooms. This is indicated by the findings that: (a) teaching are still centered on teachers, (b) one-way learning is prevailing, (c) there is no utilization of network, (d) students are not encouraged to actively conduct research, (e) the learning focus is on cyber world, (f) learning is individual, (g) knowledge is too general and mostly inapplicable in the real life, and (h) there is only one type of stimulation. To deal with these undesirable conditions, teachers' applications of scientific approach need to be reinforced so that the advantages of scientific approach can be manifested in the classrooms. The advantages of the approach gained by this study are in line with what have been revealed by A. Machin(2014:28-35), who points out that the scientific approach can: (a) increase intellectual skills, (b) build students' problem-solving skills, (c) make students regard their learning as a need, (d) promote good learning results, (e) train students how to communicate their ideas, and (f) improve students' personal characters.

Corresponding Author:-ArisBadara. 


\section{Research Method:-}

The current study reports on what have been discovered in stage I, which were accomplished by: (a) compiling theories related to scientific approach, (b) identifying components of scientific approach that need reinforcement, especially in the teaching of bahasa Indonesia, (c) conducting a need analysis through in-depth interview, questionnaire, as well as studying teacher's portfolio and running focused group discussionwith stakeholder in the field ofeducation.

\section{Technique of Data Collection:-}

Data of this study were collected by conducting indepth interview, studying documents (documentation), and doing participatory observation. To maintain the validity of data obtained from the respondents, the researcher run a triangulation ofsources from the informants until a saturation point is achieved.

\section{Technique of Data Analysis:-}

Data were analyzed using Miles danHuberman's (1987) technique of interactive analysis, which includes; data reduction, data presentation, and verification/drawing of conclusions. The following figure shows the scheme of data analysis.

\section{Results:-}

The Implementation of Scientific Approach:The Observing Method in Language Teaching:-

Whenapplying the observation method, the teacherstried to make learning more meaningful. This method has several strengths - it uses real objects as teaching media, it makes students feel happy and challenged, and it is relatively easy to do, to name a few. Theobservation stage was proved to be very useful for students to satisfy their curiosity, making their learning more meaningful. The teachers also facilitated students in the observation, showing them how to attend to important aspects of an object or media. This was in accord with the competence the students are expected to achieve, namely, studiousness and thoroughness in searching for information.

From the above description, it was clear that the teachers did apply the scientific approach in their teaching. At the beginning of the lesson, their students were split into 5 groups. During this activity, the teachers oversaw the students seriously reading two different texts. Then, the teachers asked the students to work in groups and identify the similarities and differences of the two texts, which they would later need to be able to compose a complex procedure text. During the observation stage,the teachers occasionally directed and guided the students in their observational activity.

It could also be seen that in this stage each group of students worked carefully to search for and spot the differences of the two texts. After that, the students documented what they had found from the text.

\section{The QuestioningMethod in Language Learning:-}

In the questioning stage, the teachers provided ample opportunities for the students to ask anything about what they had seen, read, listened, or observed. Then, the students were guided into making their own questionsrelated to the object they have observed, be it concrete or abstract,or anything pertaining to the fact, concept, principle, procedure, or other abstract stuff. The questions asked ranged from factual to hypothetical. Some students, however, were still unable to make questions on their own, so the teachers guided them through the process ofconstructingboth simple and difficult questions. In this stage, it was obvious that the teacher tried to stimulate the students to ask questions concerning the learning topic. During this time, some question-and-asnwersessions occurred between the students and the teacher, between the students and other students, and between the teachers and the students

The researcher also noticed that in the question-answer sessions the teachers tried to stimulate the students' response, guiding them so that they were able to identify the similarities and differences of the two complex procedure texts that they have just read. This was intended to develop the students' imagination and creativity so that they could determinewhich sentences construct the texts. The teacher also provided reinforcements to the students' answers.

In this questioning stage, the students were seen to ask questions to each other, trying to confirm the characteristics of the texts in the event when there was any discrepancy in the students' findings. Afterwards, the students tried to make some definitions on the basis of what they had discovered. This was done to help the students acquire 
expected competences, i.e., to develop creativity, curiosity, and ability in formulating questions in order to build their critical thinking skills.

\section{The Exploring Method in Language Learning:-}

The next stage was collecting information or exploring, which wasa follow-up to the questioning stage. In this stage, the students were asked to usea variety of sources and means to search for and collectinformation. For this purpose, the students were suggested to read more books, to look into the phenomenon or object more carefully, or to experiment with what they had learnt. Through this activity, a number of information needed could be collected.Result of this study shows that the teacher utilized a variety of sources and learning media. The teacher asked the students to go to the Internet and search for information about complex procedure text. The students were given a high degree of freedom to search for and collect information from various sources and media. This was intended to help the students acquire the expected competences, namely to develop meticulousness, honesty, politeness, and respect to other's opinion.

\section{The AssociatingMethod in Language Learning:-}

The associating method is a stage in the scientific approach in which the information obtained from the previous stage are processed.In this stage, what were processed were not only the information that adds to the extent and depth of learning materials but also those that offer solutions. The purpose of this activity was to find out the relationship between one information and the other, as well as to determine the pattern of the relationship.

Based on the data obtained in the field, it was clear that the teacher tried to create a meaningful learning. During the learning process, the students worked in groups and actively processed the information they had gathered in the previous stage. They were busy discussing the topic with the other members of their group. In the discussion, some tried to argue and defend their opinions. Then, each group reached a decision about the task given by the teacher.

After the associating stage, the teacher moved to the concluding stage. In the scientific approach, this stage comesafterthe activity when the students process data or information. After the students established the connection between the information and the pattern of the connection, they drew some conclusions.

\section{The Communicating Method Language Learning:-}

In alearning which applies the scientific approach, teachers should provide students with an opportunity to communicate what they have learnt. A communicating activity is a process of presenting observation results, analysis of the findings, and conclusions, which can be done orally or in written. The activity can be accomplished by writing down or describing what have been found in the previous stages (i.e., collecting information, associating, and finding of the pattern). The results are reported to the class and are counted by teachers as the learning results achieved by each student or group of students.

Result of observing the learning process shows that the students were enthusiastic enough to report their group's work. After each group was done with their report, the teacher invited other groups to comment on the work being reported. In this activity, some students were seen to be working actively in their groups, while a few others were not.

In the communicating activity, the teacher assessed what have been done by the students. The teacher also announced which group did the best work. This was intended to motivate the students to do better in the next lessons. Result of the observation also shows that the teacher applied the scientific approach in the teaching process and complied with the characteristics of 2013 curriculum. Through this activity, the students are expected to be able to acquire a number of competences, including the ability to be honest and tolerant, to think systematically, to express their opinions concisely and clearly, and to use language proficiently.

\section{The Application of Scientific Approach:-}

Findings of this study indicate that while the teachersdid apply scientific approach, they did it without following the procedure of the approach. For example, they did not use any teaching methods associated with the approach, such as problem-based learning, project-based learning, or discovery learning.

In addition, scientific approach must also be guided by scientific principles. The approach is characterized by its emphasis on the dimensions of observation, association, discovery, validation, and explanation of truths. Therefore, 
all learning processes must comply with the scientific values, principle, or criteria. Findings of this study show that several components of the scientific approach that were applied by the teachers need to be reinforced, due to the followings

a) Several teachers were still unable to inspire and encourage their students to think critically, analytically, and correctly when identifying, understanding, and solving problems, as well as when applying the substance of materials that they were learning.

b) In many occassions, the teachers were still unable to encourage and inspire their student to think hypothetically.

c) The teachers were also unable to inspire their students, causing them unable to understand, apply, and develop a rational and objective mindset.

d) Some teacherswereunable to develop accountable concept, theory, and empirical facts.

On top of these, the teachers often involved non-scientific characters or values in their teachings, as shown in the use of: (a) intuition, (b) common sense, (c) prejudice, and (d) trial-and-error approach.The following provides a complete, detailed account of these non-scientific natures.

\section{A Model for Reinforcing the Implementation of Scientific Approach:- Reinforcing Observation Methodin Language Teaching:-}

A learning model is an applicative framework of an approach, method, and teaching technique. Therefore, scientific approach should be applied by using the following learning models: (a) inquiry learning, (b) discovery learning, (c) project-based learning, and (d) problem-based learning. These models are compatible with the characteristics of scientific approach. Albanese and Mitchel (Tan, 2004:7) point out that problem-based learningwill help students construct concepts as well as develop process skills in their learning. OonSen Tan (Rusnayati, 2011) supports this view, stating that when learners are posed with problems, they will be challenged to think harder. In light of this, what follows is a model for reinforcing scientific approach when it is applied through learning models that are compatible with the characteristics of the approach.

When using an observation method, teachers should emphasize on meaningful learning. Teachers should prepare real object for students to observe. This method is simple to apply and enjoyable to students, but it takes time to prepare it well. Quite a lot of cost and energy are also needed. If the implementationof this method is ill-controlled, the meaning and purpose of learning might be vague.

If a teacher wishes to satisfy students' curiosity, he/she needs to use the observation method. This will make learning more meaningful since the students will discover facts that are related to the learning material being analyzed.

To reinforce the application of scientific approach in the classrooms, teachers should take the following steps:

a) plan and decide what object(s) to be observed,

b) planand draw up an observation guideline according to the scope of the object(s) to be observed,

c) determine clearly what types of data to be observed,

d) determine where the observation will take place,

e) determine clearly how the observation should be conducted, and

f) determine how to document the observation results.

Most importantly, all students must be required to participate directly and actively in theobservation process.

The followinga are several models of observation that teachers can employ to involve all students.

a. Common observation, in whichstudents are the ones conductinga full observation (complete observer) and they do not at all involve themselves in the doer, object, or situation being observed.

b. Controlled observation, in whichstudents do not at all involve nor associate themselveswith the doer, object, or situation being observed.

c. Participant observation, in whichstudents directly involve themselves in the object being observed.

It must be noted that these models can be implemented effectively if teacher and students equip themselves with note-taking tools, such as: (1) tape recorder, to record what happens, (a) camera, to visually capture objects; (b) videoor movie recorder, to record audio-visual objects, and (c) other necessary tools. 
Teachers can prepare instruments such asa checklist (a list of objects to be observed), a rating scale (to take note of phenomena according to their degree), an anecdotal record (a note made by students and teachers to record any extraordinary behaviors exhibited by objects being observed), and mechanical tools (to capture or to record certain events related to the subject).

\section{Reinforcing Questioning Method in Language Learning:-}

An innovative teacher is one that is capable of inspiring his/her students to increase and develop their attitude, skills, and knowledge. When a teacher asks questions, at the same time he/she guide the students into how to learn well. When he/she answers questions, he/she at that time encourages the students to become good listeners and good learners.

Unlike an assignment which requires real actions, questions are meant to receive verbal responses. A "question" does not always realized in an "interrogative sentence." It can also use a statement, as long as it expects verbal responses. To reinforce the implementation of questioning method, teachers should

a) Spark students' curiosity, interest, and attention to the learning theme or topic.

b) Encourage and inspire students to learn actively and to develop questions by and for themselves.

c) Diagnose students' difficulties and advise them of what can be done to deal with the problems.

d) Structure the tasks and provide students with opportunities to demonstrate their attitudes, skills, and understanding of the substance of the material being learnt.

e) Increase students' skills of speaking, asking questions, and giving logical answers in a systematic way, and using good language correctly.

f) Encourage students to discuss, argue, develop their thinking ability, and draw conclusions.

g) Build open attitudes towards giving and taking each other's idea or opinion, enrich vocabulary, and develop social tolerance in their group's life.

h) Get the learners into the habit of thinking fast and thinking spontaneously, as well as giving a quick response to any problem that suddenly appears.

i) Get students to practice talking politely and develop their ability to have an empathy to others.

It is very important to reinforce the questioning method since it will have a positive effect on students' learning results. This is in line with a research conducted by Sugiyanto, which concluded that an increase in teachers' skill of asking questions will lead to the students' ability to answer questions and express opinion.

\section{Reinforcing Associating Method in Language Learning:-}

To reinforce the application of associating method which aims to develop students' reasoning ability, the followings can be done:

a) Learning materials need to be organized in a way that is readily compatible with curriculum demands.

b) Lecturing method should not be overused. Teachers' main job is to provide clear, brief instructions accompanied with a model, demonstrated by either the teachers or through a simulation.

c) Learning materials should be organized hierarchically.

d) Learning activities should be oriented towards measurable and observable results.

e) All errors must be immediately corrected or revised.

f) Exercises need to be done repeatedly to habitualize expected behaviors.

g) Assessment should be based on real behaviors.

h) All students' progress should be well-documented, and remedial treatmentsmust be given when needed to improve students' learning results.

Reinforcing Analogy Method in Language Learning:-

During a learning process, teachers and students are often presented with analogous phenomena. Thus, they often needto think analogically. Analogy is a process of reasoning by comparing similar essensial natures. Thinking analogically is important in learning since it will sharpen students' reasoning skills. Like reasoning, there are two types of analogy, i.e., inductive analogy and deductive analogy.

Inductive analogyis based on a similarity of two phenomena. Based on this similarity, it can be concluded that what exists in the first phenomenon also occurs in the second one.Inductiveanalogyis a 'reasoning method' that is very important to be able to draw acceptable conclusions since it is based on the similarities that exist in the two phenomena being compared. 


\section{Reinforcing ExperimentingMethod in Language Learning:-}

To achieve real or authentic results of learning, students must conduct experiments on relevant material or substance. Students must also possesssome process skills needed to develop their knowledge about the environment around them, and they must be able to use a scientific method and behave scientifically to deal with problems in their daily life.

The experimentingmethodis intended to develop all domains of learning, i.e., attitude, skills, and knowledge. To reinforce the implementation of the experimenting method teachers should: (a) define the purposes of the experiment the students are going to do, (b) prepare materials for the experiment, (c) plan the experiment venue and time, (d) prepare working tools, (e) define the problems to be experimented, (f) hand out worksheets to students, (g) guide the students through the experiment process, and (h) collectand evaluate students' work.

In a learning process, the experimenting method need go through three stages: (a) preparation; (b) implementation, (c) follow-up. In the preparation stage, teachers should: (a) define the purposes of the experiment, (b) prepare materials or tools, (c) select a suitable venue of experiment according to the number of the students.

In the implementation stage, tecahers need to: (a) guide and observe the experimnet process; and (b) atttend to the whole situation, which includes helping students dealwith and solve any problems that affect the learning process.

In the follow-up stage, teachers are required to: (a) collect students' report of their experiment results, (b) check the students' experiment result, (b) offer feedbacks on the students' result of experiment, (c) get all students to discuss problems they encountered during the experiment, (c) work together with all students to check and restore all materials and tools they have used in the experiment.

The following is a graphical representation of a model for reinforcing scientific approach. 


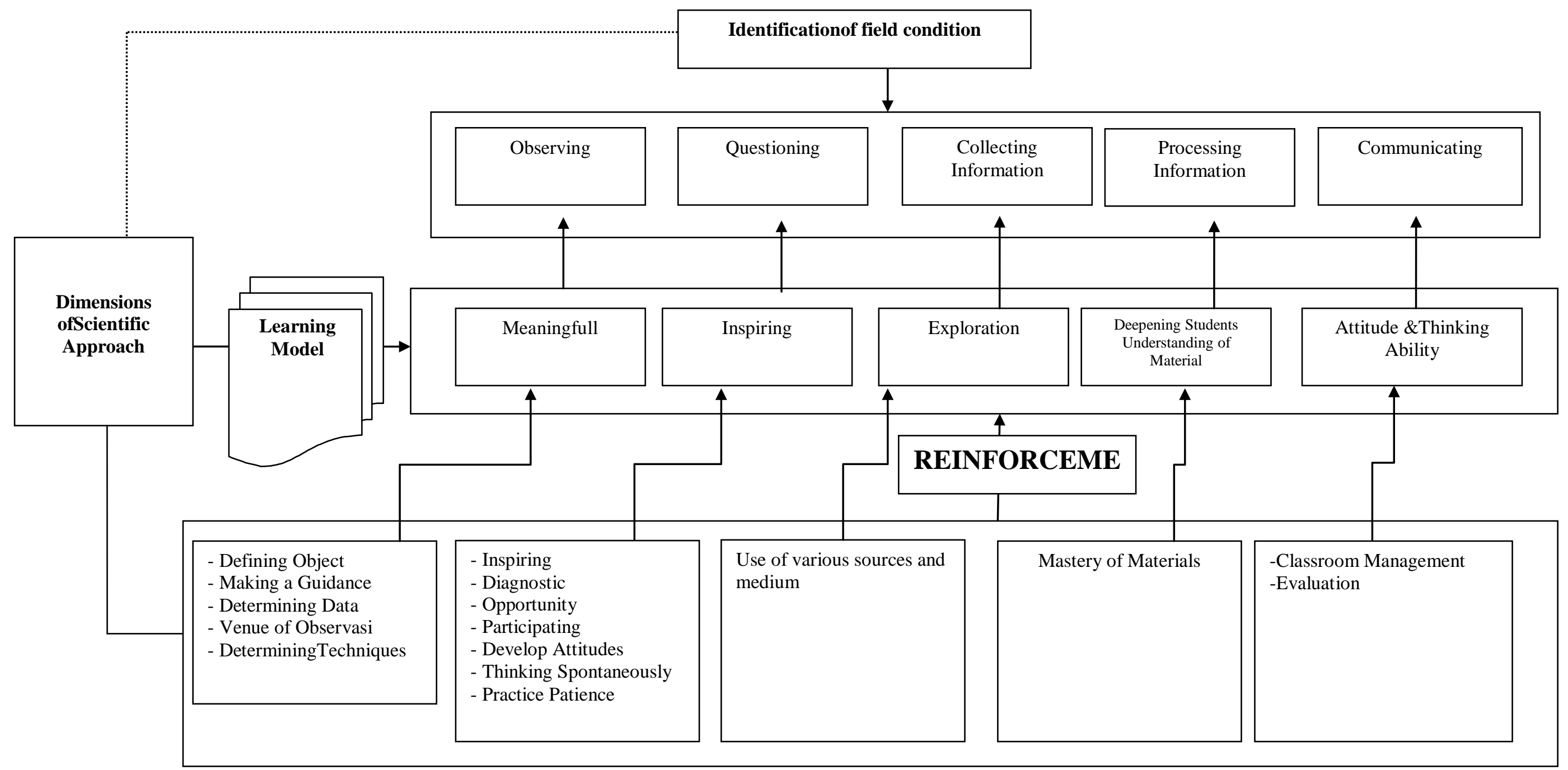




\section{Conclusion:-}

Based on the results of the research presented above, the followings conclusions are drawn.

Some aspects in the application of scientific approach need to be reinforced due to the fact that teachersgenerally:(a) still provide explanations on the basis of subjective thinking, (b) are unable yet to inspire and encourage students, (c)are unable yet to inspire students, (d) are unable yet to encourage and inspirasi students, (e) are unable yet to develop accountable concept, theory, and empirical facts.

For these reasons, reinforcementsare needed so that teachers can: (a) emphasize on meaningful learning, (b) increase reasoning ability, (c) minimize the use of lecturing method, (d) create a learning that is oriented to measurable results, (f) carry out drills and exercises in a systematic way,and (h) document all students' progress.

\section{Bibliography:-}

1. Machin, A. 2014. Implementasi Pendekatan Saintifik, Penanaman Karakter dan Konservasi Pada Pembelajaran Materi Pertumbuhan. JPII 3 (1) (2014) 28-35. JurnalPendidikan IPA Indonesia. http://journal.unnes.ac.id/nju/index.php/jpii

2. jurnal.upi.edu/file/06._Resti_Fauziah_165-178pdf_.pdf, INVOTEC, Volume IX, No.2, Agustus 2013 : 165-178.

3. Tan, OonSeng. (2004). Enhancing Thinking through Problem Based Learning Aproaces. Singapore: Thomson Learning.

4. Rusnayati, HenidanEkaCahya Prima. Penerapan Model Pembelajaran Problem Based Learning dengan Pendekatan Inkuiri untuk Meningkatkan Keterampilan Proses Sains dan Penguasaan Konsep Elastisitas pada Siswa SMA (Prosiding Seminar NasionalPenelitian, Fakultas MIPA, UniversitasNegeri Yogyakarta, 14 Mei 2011).http://file.upi.edu/Direktori//Publikasi/42PFis_Heni.pdf.

5. Miles danHuberman. 1994. Qualitative Data Analysis. A Shoursce Book of a New Method. London \& New Delhi. Diterjemahkanoleh: TjetjeprohandiRohidi. 1996. Analisis Data Kualitatif. Jakarta UI Press 